Pengaruh Karakteristik Perusahaan Terhadap Luas Pengugkapan

Corporate Social Responsibility (CSR) Perusahaan Manufaktur

Yang Terdapat Di Bursa Efek Indonesia Tahun 2012-2013

ISSN: $1412-629 X$

\title{
PENGARUH KARAKTERISTIK PERUSAHAAN TERHADAP LUAS PENGUNGKAPAN CORPORATE SOCIAL RESPONSIBILITY (CSR) PERUSAHAAN MANUFAKTUR YANG TERDAFTAR DI BURSA EFEK INDONESIA TAHUN 2012-2013
}

\author{
Monot Wicaksono ${ }^{1)}$, Paryanto ${ }^{2)}$ \\ 1) Program Studi S1 Akuntansi, STIE-AAS Surakarta \\ monotwicaksono@gmail.com \\ 2) Program Studi D3 Pajak, STIE-AAS Surakarta \\ Paryanto@gmail.com
}

\begin{abstract}
This study aims to examine the causal relationship of corporate characteristics to corporate social responsibility disclosure on manufacturing companies listed in Indonesia Stock Exchange 20122013. This research uses secondary data that is company annual report obtained from www.idx.com and company website during period 2012-2013. The sample selection process is done by using cluster sampling method. The analysis method used is multiple regression analysis consisting of classical assumption test (normality test, multicolinearity test, heteroscedasticity test, and autocorrelation test) and hypothesis test (coefficient of determination, $t$ test, $F$ test). The results of this study indicate that profitability, liquidity, company profile has no effect on CSR disclosure. F test results show that the independent variables simultaneously affect the dependent variable.
\end{abstract}

Keywords: Corporate Characteristics, Corporate Social Responsibility, IDX

\section{PENDAHULUAN}

Corporate social responsibility merupakan tanggung jawab sosial perusahaan dalam melakukan kegiatan usahanya, baik terhadap masyarakat maupun lingkungan sekitarnya atas segala hal yang menyebabkan lingkungan terkena pengaruh negatif atas usaha perusahaan. CSR meskipun berupa tindakan sosial, tetapi berimbas pada pengaruh persaingan pula. Pasar modal dalam hal ini bursa efek Indonesia menjadi bagian yang tak terelakkan dari kegiatan-kegiatan perusahaan. Sektor pasar modal Indonesia juga kurang mendukung dengan belum adanya penerapan indeks yang memasukkan kategori sahamsaham perusahaan yang telah mempraktikkan CSR. Sejak tanggal 23 september 2007, pengungkapan tanggung jawab sosial perusahaan (corporate social responsibility disclosure) mulai diwajibkan melalui UU Perseroan Terbatas Nomor 40 tahun 2007, khususnya untuk perusahaan-perusahaan yang hidup dari ekstraksi sumber daya alam (Nasir et al., 2013:2).

Kasus-kasus yang terkait dengan lingkungan yang dilakukan oleh perusahaan terhadap masyarakat dan lingkungan sekitar perusahaan, seperti kasus Lapindo yang dinobatkan sebagai perusahaan paling tidak bertanggung jawab sosial, kasus tuduhan pencemaran Teluk Buyat oleh PT Newmont Minahasa Raya serta kasus PT Freeport Indonesia yang akhirnya menyebabkan Kementerian Lingkungan Hidup pun mempublikasikan temuan pemantauan dan penataan kualitas lingkungan di wilayah penambangan PT Freeport Indonesia yang hasilnya, Freeport dinilai tak memenuhi batas air limbah dan telah mencemari air laut dan biota laut, mendorong pemerintah untuk menerbitkan regulasi yang mengatur tentang corporate social responsibility (selanjutnya disebut CSR) yaitu UU No. 40 Tahun 2007 
Pengaruh Karakteristik Perusahaan Terhadap Luas Pengugkapan

Corporate Social Responsibility (CSR) Perusahaan Manufaktur

Yang Terdapat Di Bursa Efek Indonesia Tahun 2012-2013

tentang Perseroan Terbatas (Arifin et al., 2011:1).

Dalam Pasal 74 Undang-Undang tersebut diatur tentang kewajiban pengungkapan tanggung jawab sosial dan lingkungan perusahaan.Pertanggungjawaban sosial perusahaan atau Corporate Sosial Responsibility (CSR) merupakan suatu tindakan atau konsep yang dilakukan oleh perusahaan (sesuai kemampuan perusahaan tersebut) sebagai bentuk tanggung jawab mereka terhadap sosial dan lingkungan sekitar dimana perusahaan itu berada. Contoh bentuk tanggung jawab itu bermacam-macam, mulai dari melakukan kegiatan yang dapat meningkatkan kesejahteraan masyarakat dan perbaikan lingkungan, pemberian dana untuk pemeliharaan fasilitas umum, sumbangan untuk desa atau fasilitas masyarakat yang bersifat sosial dan berguna untuk masyarakat banyak, khususnya masyarakat yang berada disekitar perusahaan tersebut (Nasir et al., 2013:3).

Belum semua perusahaan melakukan Tanggung Jawab Sosial (CSR), melaporkan dan mengungkapkan kegiatan Tanggung Jawab Sosialnya. Berdasarkan penelitian yang dilakukan oleh KAP KPMG persentase perusahaan yang melaporkan pada inisiatif CSR

2008-2011 meningkat dari $74 \%$ menjadi $83 \%$ di Amerika Serikat, dari 62\% menjadi $79 \%$ di Kanada, dan dari $91 \%$ menjadi $100 \%$ di Inggris. Berdasarkan survei tersebut dapat dilihat persentase peningkatan perusahaan yang melaporkan pada inisiatif CSR di wilayah Amerika dan Inggris mengalami peningkatan 9\%, sedangkan di wilayah Kanada mengalami peningkatan $17 \%$ selama 4 tahun (KPMG, 2011 dalam Sagara, 2014:1).

Fenomena yang terjadi di Indonesia konsep CSR sudah mulai disadari perusahaanperusahaan besar, contohnya program community development yang dijalankan hampir semua perusahaan besar maupun Program Kemitraan dan Bina Lingkungan (PKBL) oleh Badan Usaha Milik Negara (BUMN) menjadi bukti bagaimana korporasi menerangkan konsep CSR, juga penerapan CSR oleh Hongkong and Shanghai Banking Corporation Limited (HSBC) yang memberikan perhatian khusus di bidang pendidikan, lingkungan hidup, dan sosial (Sagara, 2014:1).

Padahal jika kita lihat, walaupun CSR ini merupakan tanggung jawab sosial, tetapi juga berpengaruh terhadap persaingan usaha, karena perusahaan yang mau mengeluarkan CSRnya pasti akan diperhatikan pula oleh masyarakat (pelanggan). Thoin (2011) Perkembangan zaman telah begitu pesat, khususnya dalam persaingan usaha, dimana CSR ikut menentukan persaingan.

Penelitian ini bertujuan untuk menganalisa hubungan kausalitas yang digunakan untuk menjelaskan pengaruh karakteristik perusahaan (yang diproksikan dengan profitabilitas, likuiditas, profil perusahaan) dan regulasi pemerintah terhadap pengungkapan corporate social responsibility. Populasi penelitiana dalah perusahaan manufaktur yang terdaftar di BEI tahun 20122013.

\section{KAJIAN PUSTAKA}

Corporate Sosial Responsibility (CSR) adalah bentuk tanggung jawab dari setiap perusahaan terhadap lingkungan terutama kemungkinan kerusakan lingkungan yang semakin parah, sehingga anak cucu kita kelak tidak semakin menanggung beban yang lebih berat dibandingkan dengan generasi sekarang (Saiman, 2009:297)

Pengungkapan adalah pengeluaran informasi yang ditujukan bagi pihak-pihak yang berkepentingan. Tujuan dari pengungkapan corporate social responsibility 
Pengaruh Karakteristik Perusahaan Terhadap Luas Pengugkapan

Corporate Social Responsibility (CSR) Perusahaan Manufaktur

Yang Terdapat Di Bursa Efek Indonesia Tahun 2012-2013

(CSR) adalah agar perusahaan dapat menyampaikan tanggung jawab sosial yang telah dilaksanakan perusahaan dalam periode tertentu.Penerapan corporate social responsibility (CSR) dapat diungkapkan perusahaan dalam media laporan tahunan (annual report) perusahaan yang berisi laporan tanggung jawab sosial perusahaan selama kurun waktu satu tahun berjalan (Sari, 2012:128).

\section{Profitabilitas}

Kusnadi et al., (2002) dalam Wakid et al., (2012: 7) menjelaskan bahwa profitabilitas merupakan hasil akhir dari keseluruhan kebijakan dan keputusan yang dipilih oleh manajemen organisasi bisnis. Seluruh kebijakan apapun yang ada di dalam organisasi jika berjalan baik dan berdampak positif akan menghasilkan kinerja yang efektif dan efisien sehingga akan menghasilkan tingkat keuntungan perusahaan yang memuaskan. Menurut Lucyanda dan Siagian (2012:604):

H1: Profitabilitas berpengaruh terhadap pengungkapan CSR

\section{Likuiditas}

Likuiditas saham menurut Bursa Efek Indonesia (Informasi Umum Pasar Modal, Stock Exchange) dalam Santoso dan Linawati (2014:59) adalah kelancaran yang menunjukan tingkat kemudahan dalam mencairkan modal investasi. Secara umum, Sharpeet al., (1999) dalam Santoso dan Linawati (2014:59) mendefinisikan likuiditas sebagai kemampuan investor menjual harta atau asset yang dimilikinya tanpa harus melakukan konsesi atau kelonggaran harta.

H2: Likuiditas berpengaruh terhadap pengungkapan CSR

\section{Profil Perusahaan}

Profil perusahaan adalah uraian tentang bidang operasi yang dijalankan oleh perusahaan (Rahman dan Widyasari, 2008 dalam Wakid, et al., 2012:8). Hubungan antara profil perusahaan dengan pengungkapan tanggung jawab sosial dapat dikaitkan dengan variasi dampak operasi perusahaan terhadap lingkungan dan masyarakat. Industri high profile sebagai industri yang memiliki consumer visibility, risiko politik yang tinggi, atau kompetisi yang tinggi akan lebih memperhatikan pertanggungjawaban sosialnya kepada masyarakat karena hal ini akan meningkatkan citra perusahaan dan dapat memengaruhi tingkat penjualan

H3: Profil perusahaan berpengaruh terhadap pengungkapan CSR

Berdasarkan latar belakang masalah di atas dan landasan teori yang telah dipaparkan sebelumnya, maka model penelitian ini dapat digambarkan sebagai berikut.

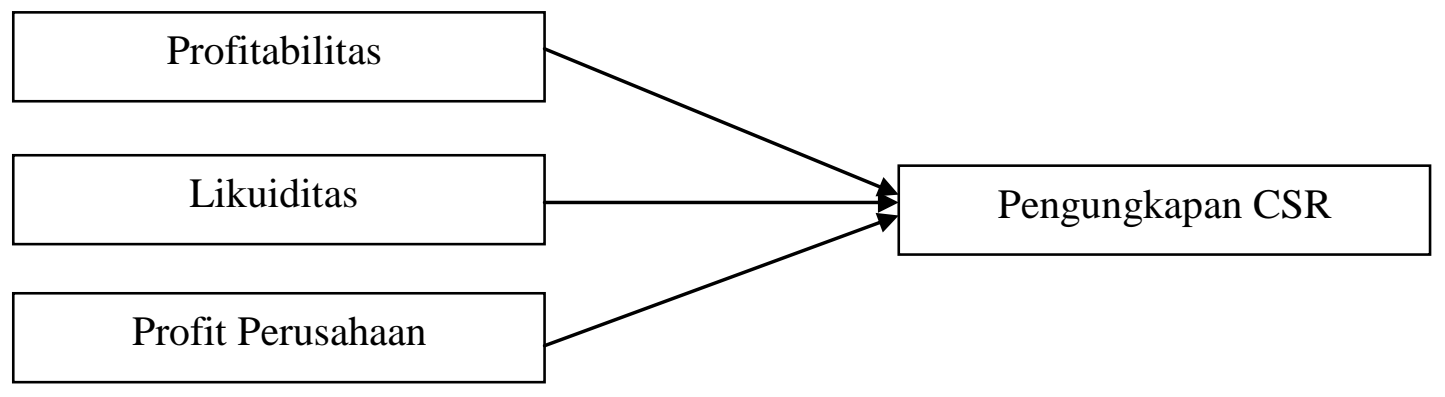


Pengaruh Karakteristik Perusahaan Terhadap Luas Pengugkapan

Corporate Social Responsibility (CSR) Perusahaan Manufaktur

Yang Terdapat Di Bursa Efek Indonesia Tahun 2012-2013

ISSN: $1412-629 \mathrm{X}$

\section{METODE PÉNELITIAN}

Penelitian ini menggunakan populasi perusahaan manufaktur yang terdaftar di BEI tahun 2012-2013. Fokus penelitian ini adalah ingin melihat pengaruh Karakteristik perusahaan terhadap pengungkapan corporate social responsibility pada perusahaan-perusahaan manufaktur yang masuk di dalam BEI.

Dalam penelitian ini metode yang digunakan untuk memilih sampel adalah metode cluster sampling. Penelitian ini mengambil sampel selama 2 tahun, yaitu dari tahun 2012-2013. Penelitian secara cluster sampling mengindikasikan bahwa sampel yang digunakan dalam penelitian ini merupakan representasi dari populasi yang ada, serta sesuai dengan tujuan dari penelitian.

\section{HASIL PENELITIAN DAN PEMBAHASAN}

\section{Hasil Uji Signifikansi Parameter}

\section{Individual (Uji t)}

Berdasarkan tabel, hasil uji $\mathrm{t}$ dapat dijelaskan sebagai berikut.

1. Hasil uji regresi linier berganda menunjukkan signifikansi 0,215 >0,05. Dapat diartikan bahwa profitabilitas tidak berpengaruh terhadap pengungkapan corporate social responsibility. Hasil yang sama juga ditemukan dalam penelitian yang dilakukan oleh Nazir et al., (2013) dan Wakid et al., (2012).

2. Hasil uji regresi linier berganda menunjukkan 0,694 > 0,05. Dapat diartikan bahwa likuiditas tidak berpengaruh terhadap pengungkapan corporate social responsibility. Hasil yang sama juga ditemukan dalam penelitian yang dilakukan oleh Kamil dan Herusetya (2012).
3. Hasil uji regresi linier berganda menunjukkan signifikansi 0,678 >0,05. Dapat diartikan bahwa profil perusahaan tidak berpengaruh terhadap pengungkapan corporate social responsibility. Hasil yang sama juga ditemukan dalam penelitian yang dilakukan oleh Wakid et al., (2013).

\section{Hasil Uji Signifikansi Parameter Simultan (Uji F)}

Data menunjukan hasil uji statistik F terhadap variabel-variabel independen dan variabel dependen. Hal itu menunjukkan bahwa profitabilitas, likuiditas, profil perusahaan secara simultan berpengaruh terhadap pengungkapan corporate social responsibility. Hal tersebut dibuktikan dengan tingkat signifikansi 0,000 lebih kecil dari 0,0

\section{KESIMPULAN}

Dapat disimpulkan bahwa profitabilitas, likuiditas, dan profil perusahaan secara simultan berpengaruh terhadap pengungkapan corporate social responsibility. Dengan kata lain profitabilitas, likuiditas, profil perusahaan tidak berpengaruh terhadap pengungkapan CSR. Hasil Uji F menunjukan bahwa variabel independen berpengaruh secara simultan terhadap variabel dependen.

\section{DAFTAR PUSTAKA}

Arifin, Bustanul, Yeni Januarsi dan Faoziah Ulfah. (2011). "Perbedaan Kecenderungan Pengungkapan Corporate Social Responsibility : Pengujian Terhadap Manipulasi Akrual Dan Manipulasi Real". Jurnal Universitas Sultan Ageng Tirtayasa. 
Kamil, Ahmad dan Antonius Herusetya. (2012). "Pengaruh Karakteristik Perusahaan Terhadap Luas Pengungkapan Kegiatan Corporate Social Responsibility. Media Riset Akuntansi, Vol. 2 Nomor 1.

Lucyanda, Jurica dan Lady Gracia Prilia Siagian. (2012). "The Influence of Company Characteristics Toward Corporate Social Responsibility Disclosure".The 2012 International Conference on Business and Management 6-7 September, Phuket Thailand. Bakrie University, Jakarta-Indonesia.

Nasir, Azwir, Pipin Kurnia dan Teguh Dheki Hakri. (2013). "Pengaruh Kepemilikan Manajerial, Leverage, Profitabilitas, Ukuran, dan Umur Perusahaan Terhadap Pengungkapan Informasi Pertanggungjawaban Sosial Perusahaan Pada Perusahaan Food And Beverage Yang Terdaftar di BEI". Jurnal Ekonomi Volume 21, Nomor 4.

Sagara, Yusar. (2014). "Pengaruh Pelaporan dan Pengungkapan Aktivitas Tanggung Jawab Sosial Perusahaan (Corporate Social Responsibility) Terhadap Kualitas Lingkungan Hidup Perusahaan Manufaktur di Indonesia. LP3M UIN Syarif Hidayatullah Jakarta. Saiman, Leonardus. (2009). "Kewirausahaan (Teori, Praktik dan Kasus-kasus)". Salemba Empat Jakarta.
Santoso, Halim dan Nanik Linawati. (2014). "Pengaruh Return dan Varian Return Anggota LQ-45 Terhadap Bid-Ask Spread". FINESTA Vol. 2, No. 2.

Sari, Rizkia Anggita. (2012). "Pengaruh Karakteristik Perusahaan terhadap Corporate Social Responsibility Disclosure pada Perusahaan Manufaktur yang terdaftar di Bursa Efek Indonesia".Jurnal Nominal/ Volume I Nomor I. Universitas Negeri Yogyakarta.

Tho'in, M. (2011). Pengaruh Faktor-faktor Kualitas Jasa terhadap Kepuasan Nasabah di Baitul Mal Wat Tamwil (BMT) Tekun Karanggede Boyolali. MUQTASID Jurnal Ekonomi dan Perbankan Syariah, 2(1), 73-89.

Wakid, Nadiah Lutfi, Iwan Triyuwono dan Prihat Assih. (2012). "Pengaruh Karakteristik Perusahaan Terhadap Pengungkapan Corporate Social Responsibility Pada Perusahaan Manufaktur Yang Terdaftar Di Bursa Efek Indonesia", Jurnal Program Pascasarjana Fakultas Ekonomi dan Bisnis Universitas Brawijaya.

www.idx.co.id. Diakses pada hari Kamis, 6 Maret 2014, pukul 19.30 WIB. 